\title{
Traditional Thick Concrete Floor Slabs - an Obstacle to the Flexibility, Energy Efficiency and Seismic Safety
}

\author{
Viktorija ALADŽIĆ, Milan KEKANOVIĆ, llija MILIČIĆ
}

\begin{abstract}
This paper considers the potential of designing and constructing floor slabs taking into account three aspects of major importance: flexibility-adaptability, energy efficiency and seismic safety. Currently traditional reinforced concrete floor slabs at least 20 centimetres thick are still designed and built. Such practice has no justification, as thick concrete floor slabs hinder architectural creativity as well as all the other aforementioned aspects. In this paper, the authors analyse and demonstrate the simultaneous correlation between flexibility-adaptability, energy efficiency, seismic safety and the mass of the floor slabs in residential buildings. Massive floor slabs limit the distance between load-bearing walls and consequently the adaptability of residential space. A large mass directly intensifies the seismic forces it induces. Thick concrete slabs have high heat capacity, as they have high mass and volume. The solution to floor slabs which satisfy all three aspects is to design and build them as waffle slabs. These two-way spanning concrete slabs have low mass, are rigid and can span the distance of more than 10 metres between two load-bearing walls. The authors of this paper suggest that floor slabs conform to the limitation in mass provided in this paper under Eq. (5) and (6). By applying this principle, architects would be able to design more flexible, adaptable, energy efficient, and seismically safe living spaces.
\end{abstract}

Keywords: adaptability; energy efficiency; floor slabs; residential space flexibility; seismic safety

\section{INTRODUCTION}

Reinforced concrete has enabled designers to increase the spans between supporting structural elements, and subsequently added to the flexibility and adaptability of residential spaces compared to the earlier traditional materials. Contemporary practice, however, does not benefit fully from this advantage of reinforced concrete as a building material, as residential buildings still primarily use reinforced concrete floor slabs at least 20 centimetres thick. Massive floor slabs limit the distance between loadbearing supporting elements and consequently the adaptability of residential spaces. At the same time, a large mass directly intensifies the seismic forces it induces. Thick and heavy concrete slabs also have a high heat capacity, as they have high mass per volume with relatively high volumetric heat capacity $\left(\mathrm{J} / \mathrm{m}^{3} \mathrm{~K}\right)$ and thus such floor slabs by no means favour energy efficiency in buildings.

In this article, the authors analyse and demonstrate the simultaneous correlation between flexibility-adaptability, energy efficiency, and seismic safety on one hand and mass of the floor slabs on the other. There is a solution to designing and constructing floor slabs which satisfy all three aforementioned aspects, and that is to design and build them as lightweight waffle concrete slabs. These twoway spanning concrete slabs have low mass, are rigid and they can span the distance of more than 10 metres between load-bearing walls. By applying this principle, architects would be able to design flexible, adaptable, energy efficient, and seismically safe living spaces. Residents of such facilities would be satisfied with the possibility of organizing their living space in line with their wishes and needs. Construction would be faster with a higher quality output and investors would have good profit combined with more competitive market prices. Each state would accordingly substantially increase energy efficiency of new buildings, as well as the safety factor in the case of seismic activity.

\section{FLEXIBILITY AND ADAPTABILITY OF RESIDENTIAL SPACE}

Flexibility and adaptability of residential space have been affected by building materials and traditional construction systems, conditioning the span between loadbearing elements. Small span between structural elements limits the ability to create flexible and adaptable housing. Flexibility and adaptability was introduced into multifamily buildings with the development of framing, and especially with the use of reinforced concrete as a construction material. The modern concept of integrating rooms into a single whole originates from the traditional structure of the palaces belonging to Japanese aristocrats, with their flexible sliding partitions called fusuma having the role of interior partition walls and shojji partitions separating the interior and exterior [1]. The opening of Japan to the West in 1853 led to the idea of a flexible living space being spread all over Europe and America. However, its full implementation in multi-family buildings depended on the development of new building materials and construction systems.

It was not until the end of the $19^{\text {th }}$ century that reinforced concrete was applied on a bigger scale in Europe and America, while during the final years of the $19^{\text {th }}$ century it appeared as a building material in the territory of Hungary (nowadays Serbia) [2]. Reinforced concrete was first used in building industrial and public buildings, mills, warehouses, and healthcare facilities, and the pioneer of this approach was François Hennebique [3]. In the early $20^{\text {th }}$ century, he designed his house Burg-la-Reine (1903), wishing to demonstrate the possibilities of reinforced concrete as a construction material. The main characteristic of the new material was that it made possible the achievement of flexibility, as well as of structural and financial efficiency simultaneously, which proved to be necessary for the design of engineering structures. However, the new material had its disadvantage - its large mass per volume of $2500 \mathrm{~kg} / \mathrm{m}^{3}$ - which again limited the span between load-bearing elements. 
The first residential building with reinforced concrete skeleton was designed and built in 1903 by Auguste Perret in Rue Franklin 25, Paris, and it represented a landmark in the development of concrete structures and their use in residential facilities. Each floor was designed as an independent unit with flexible floor layout, where partition walls were positioned freely, filling the space between load-bearing concrete pillars. Experimenting with flexible organisation in residential spaces became especially fashionable during the 1920's. Many architects contributed to this trend: Ludwig Mies van der Rohe, Frank Lloyd Wright, Walter Gropius, Gerrit Rietveld, Kathleen Eileen Gray, etc. It is believed that Walter Gropius was one of the first architects to define the concept of flexibility in 1954 by announcing that "the architect should construct a building, not as a monument, but as a wrapping for life that the building serves and that his concept should be flexible enough so that it can create a base to absorb dynamic flows of modern life" [1].

The open plan concept incorporates the concept of flexibility, while the most extreme variation of the open plan concept is the concept of a single space. There are two types of openness: internal and external, i.e. openness of the interior plan of a residential unit and openness towards the exterior. Wide use of the open plan in residential architecture occurred during the 1960's, when living rooms became connected with the dining areas and kitchens to create a single unit. There are many combinations available for integrating previously separated rooms of different function within the open plan design concept, to the very extreme of abolishing any privacy and integrating all the rooms into a single space [1].

\section{CONTEMPORARY CONCEPT OF LIVING SPACE FLEXIBILITY}

"The degree of flexibility is determined in two ways. First the in-built opportunity for adaptability, defined as capable of 'different social uses', and second the opportunity for flexibility, defined as 'capable of different physical arrangements" [4]. Achieving adaptability and flexibility of residential space in line with different lifestyles is characteristic of an ideal home [5]. Living space flexibility in the present meaning of the term includes flexibility in construction, flexibility for using spaces for different purposes, as well as flexibility or adaptability of the living space in the course of time, where during a lifetime a person is able to adjust the space to his/her evolving needs. What is of utmost importance is the fact that "Flexible housing gives its inhabitants the opportunity to get involved in the design process of creating a suitable spatial environment throughout their lifetime. This will notably present them with a sense of belonging to their living place by fulfilling their expectations as well as by adapting it to their different demands instead of taking an architecturallypredetermined approach" [6].

The idea of creating flexible floor layouts in residential buildings is certainly present nowadays, but there are major problems and obstacles to its realisation and wide application. During the last two decades, research studies dealt with different aspects of residential space flexibility,

both positive and negative, especially in situations in which flexibility and adaptability are in great demand.

Research project undertaken in Great Britain evidences that constructing apartments with flexible and adaptable floor layouts the organisation of which may be modified in line with one's lifestyle and the changes occurring in the family over time, could prove to be cheaper in the long run. Users adjust their living spaces to their needs without leaving it to search for an alternative living arrangement which might better suit the altered circumstances in their lives (new familial circumstances: marriage, children, senior household, working from home, etc.). According to this research project the main goal of investors is not for the apartments to be flexible and adaptable over time. Their aim is to sell the apartments as quickly as possible. Needs of the future owners are hardly taken into account. Users are thus forced to accept living spaces that cannot be adapted to fulfil their evolving needs, but to rather change apartments frequently, thereby stimulating real estate and construction markets.



A

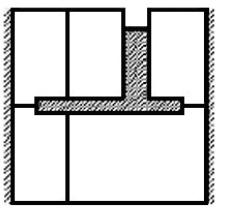

D
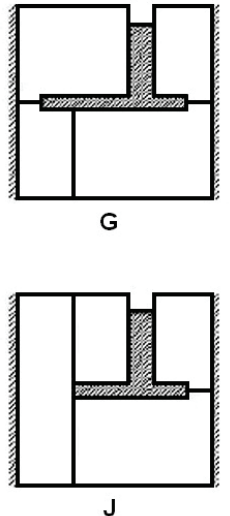

Figure 1 Potential floor layout variations involving adaptable apartments within the storey layout according to the analysis made by Professor Jovanović

Accordingly, investors are not interested to address their users' needs, but rather to generate more profit fast [4].

In Croatia, the quality of residential buildings significantly changed when compared to the period of socialism. Construction of new residential buildings is primarily undertaken by private investors, rather than by the state. Research within the project entitled "Quality of Living in New Residential Projects and Locations within Zagreb Residential Network (2013 - 2015)" undertaken in Zagreb, Zaprešić, Samobor and Velika Gorica [7], showed 
that new and often suburban housing projects have been made instantly and without plans, without respecting the process of urban planning, while the research results evidence that the quality of housing has stagnated, maybe even deteriorated when compared to the previous research. Providing that the share of the apartments with an area of 41-60 $\mathrm{m}^{2}$ is the greatest, the decrease in area compared to the previous period has been compensated with the increase in the number of rooms of reduced size and dimensions of rooms with highly reduced flexibility of the apartments.

When asked about the type of apartments that should be built in the future, Professor Goran Jovanović states that flexible floor organization is required in order to address a variety of needs of different users, i.e., to enable a high level of personalisation of the apartments [8][9]. His papers present the concept applied in the award-winning design of the residential bloc "Mosaic" in Niš. The solution provided was based on the typical floor layout of each storey, with predefined unchangeable components, such as columns, external walls, ventilation, sanitary, and communication shafts and common area of horizontal communication on each storey, as well as the envisaged loggias.

The surface area of such storey can be divided into a number of individual apartment units, with a great number of different sizes and combinations. It is possible to subsequently buy adjacent apartments and integrate them into larger residential units, as well as to divide larger apartments into smaller ones. Fig. 1 shows outlines of different combinations of apartments on different storeys. The flexible floor layout of a storey allows for various combinations of apartments of different sizes, but also flexible organisation of space within individual apartments [8]. Such spatial organisation of storeys offers a solution which would take more into account needs of the users, contrary to the current production of apartments which is made having in mind the investors' interest exclusively [9].

\section{THE NEED FOR FLOOR SLABS WITH SMALLER MASS AND LARGER SPAN}

Today, the construction of concrete floor slabs is dominant. It has a great advantage over constructing with wood or steel and it has resistance to fire and high temperatures. Concrete also has a big disadvantage, which is its large mass. In order to build flexible and adaptable residential units in reinforced concrete it is necessary to use floor slabs which can span more than 8 metres. For reinforced concrete floor slabs that span larger distances and are safer in the case of earthquakes (seismic activity), the best method is to use two-way waffle floor slabs. Solutions for such designs already exist, as shown in Fig. 2. It needs to be mentioned that classical architects implemented waffle structured systems, as in the case of the famous Pantheon built at the beginning of the first millennium (Fig. 3). As early as that, architects had already had a solution for building such an enormous dome and solve the problem of the span, so they implemented coffering with concentric and radial ribs and a slab to cover it. Making a ceiling slab lighter requires additional attention of the architects, civil engineers and investors. In the present time we are lacking this attention. The question which may arise is how come that architects, almost two thousand years ago had enough will and precision to build a structure such as Pantheon which has such a huge span between the load-bearing elements, and has lasted for so long and will probably last longer than many buildings built nowadays with the use of contemporary materials such as concrete.

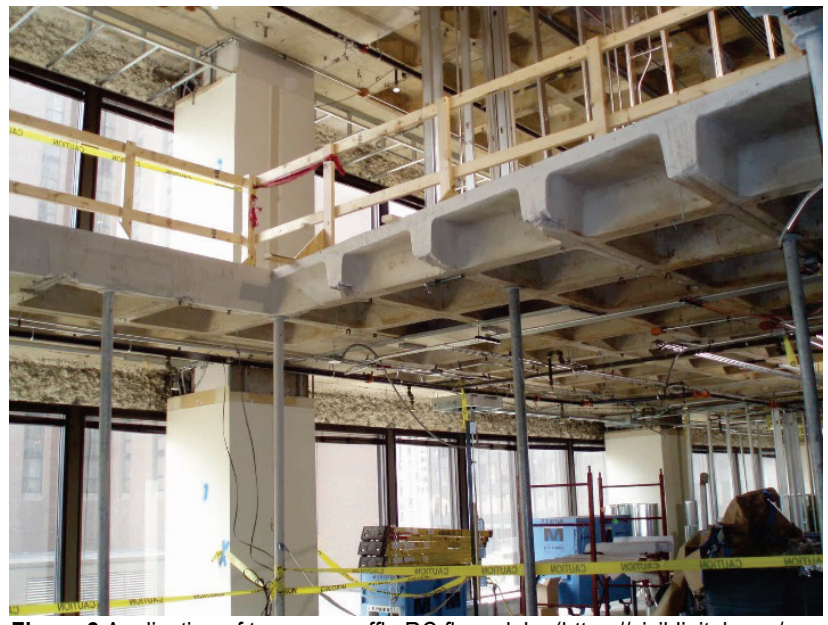

Figure 2 Application of two-way waffle RC floor slabs (https://civildigital.com/wpcontent/uploads/2014/07/waffle-slab.jpg)

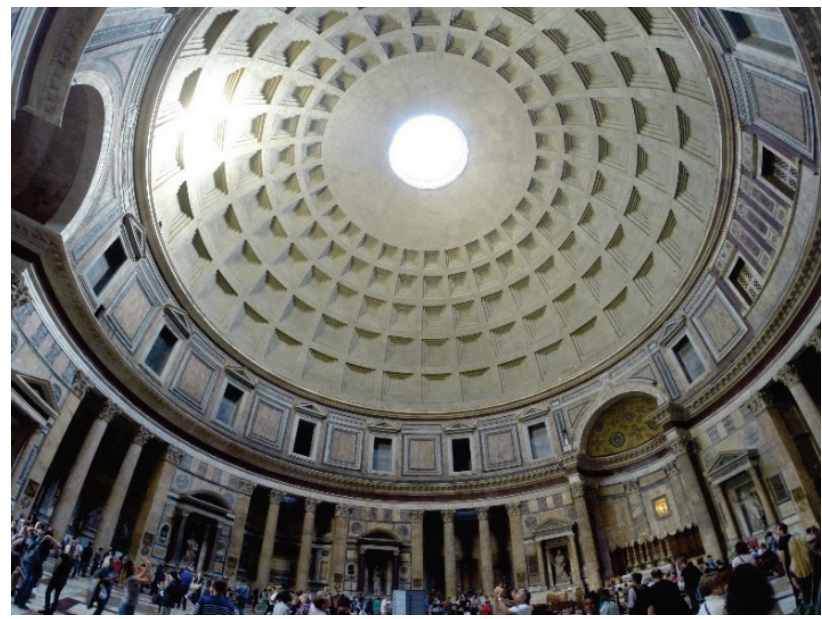

Figure 3 Coffered ceiling of the Roman Pantheon built early in the first millennium (http://www.monolithic.org/domes-more/the-pantheon-rome-126$\mathrm{ad} /$ photos)

Designers today usually opt for traditional heavy concrete slabs (Fig. 4), regardless of the fact that such solutions are out-dated and have numerous disadvantages. The reasons for such disinterest are not justified, yet it is evident that designing process is severely underappreciated by current investors who attempt to make savings wherever they can, to get designs cheaply and make maximum profit when finally selling their products. New investors lack deep knowledge of the profession and investments as a separate branch of economy and business, so they are unaware that cheap designs result in expensive buildings lacking functionality. This is particularly problematic for the buyers who pay high prices for low quality real estate products. Construction quality is more and more measured nowadays through energy efficiency monitoring and measuring of practical energy consumption for heating and cooling. Citizens and real estate buyers need to be educated in order to realise that it is in their best interest to monitor energy consumption in their apartments and offices. 
Legislation is put to practice through energy consumption monitoring, and this is effective in forcing designers and investors to pay more attention to the quality of designs and buildings. This would not diminish the profit made by designers and investors, while real estate buyers would be satisfied with functionality and the low consumption of energy for heating and cooling.

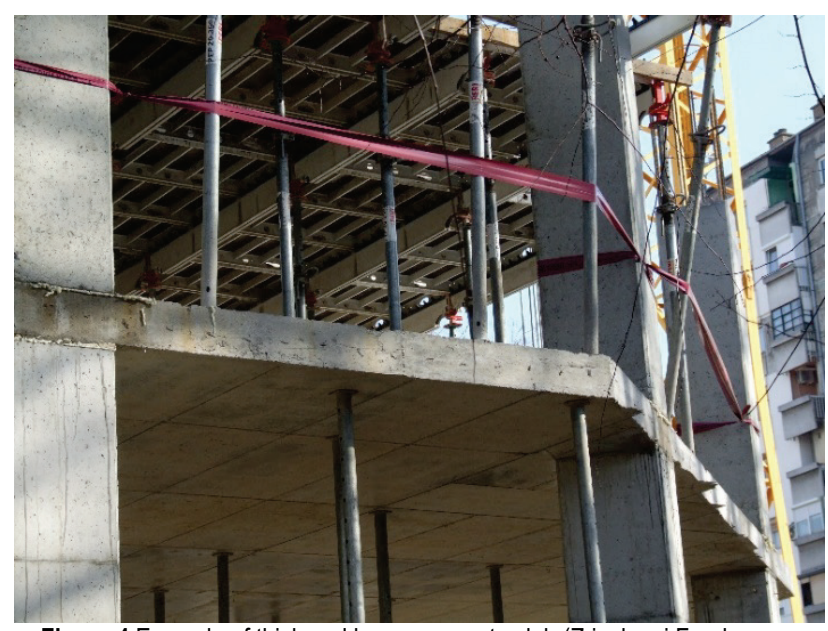

Figure 4 Example of thick and heavy concrete slab (Zrinskog i Frankopana street in Subotica)

Safety of buildings is something taken for granted in everyday conditions, yet once extraordinary stress occurs, as is the case of earthquakes, the quality of design and the building itself is put to test. It is a widely known and demonstrable fact that buildings with lighter floor slabs and walls are safer in case of seismic activity than massive structures with thick floor slabs and walls (Fig. 4).

Producers of concrete often see their interest in financially stimulating designers to use as much concrete as possible in designing a building. Thus the buildings frequently involve heavy floor slabs, at least 20 centimetres thick, which cannot span more than 6 metres, or allow functionality and adaptability of residential space.

\section{PARAMETERS IN SELECTING RC FLOOR SLABS}

This paper demonstrates the ways in which the mass of traditional solid concrete floor slabs negatively influences the adaptability, energy efficiency and seismic safety of buildings. The thickness of the floor slab must be adhered to as it dictates the rigidity of the slab, the deflection of the slab and the moment of resistance of the slab (W). Thus, the thickness of the slabs also affects the stresses in the concrete and in the reinforcement. The greater the thickness of the slab is, the moment of resistance is higher, so the stresses in concrete and reinforcement are lower. The minimum slab thickness should be determined relative to its span, using the following Eq. (1):

$d \geq \frac{L}{F}$

Where: $d$ - floor slab thickness (m); $L$ - floor slab span (clear span - span between null points in moment diagram), (m); $F-$ a constant that has been proven on the basis of previous practical construction experience and should be 30 at maximum.

In the particular example, the minimum thickness of simply supported slab of $8 \mathrm{~m}$ clear span, with the moment diagram's null point spacing of $L=8 \cdot 1,05=8,4 \mathrm{~m}$, should be as follows:

$$
d \geq \frac{8 \cdot 1,05}{30}=0,28 \mathrm{~m}
$$

The slab thickness of $0,28 \mathrm{~m}$ is large, and if it is made of solid concrete, it would have a large weight, which would also greatly increase the amount of steel reinforcement within the concrete. The price of such a slab would also be high because the steel reinforcement is quite expensive. These are the main reasons why today's residential buildings are not constructed with slabs of longer span, which would allow for flexible and adaptable construction of residential buildings. The authors of this work consider that the problem of large weight of solid concrete floor can be overcome by waffle slabs with oneor two-way ribs, which would have the prescribed thickness, stiffness and moment of resistance, but much lower weight. In this way, sufficiently stiff, waffle floor slabs of prescribed thickness, but of reduced weight, could successfully be used for longer spans and enable designing adaptable and flexible space of residential buildings.

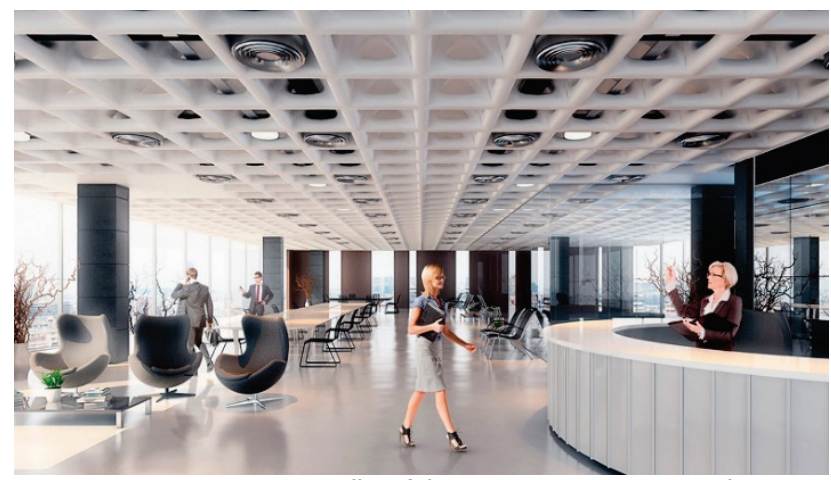

Figure 5 Holedeck two-way waffle RC floor slab as an ideal solution for large spans and therefore adaptable, energy efficient and seismically safe public and residential buildings (http://holedeck.com/en/edificacion-en-altura/)

As has already been mentioned, there is another major disadvantage of thick concrete floor slabs, i.e., the increased seismic destructive force, $S$, induced [10]. The bigger the mass of a building, $G(\mathrm{kN})$, the stronger the force, $S(\mathrm{kN})$, as is shown in the Eq. (2).

$S=K \cdot G$

Where: $S$ - Horizontal force caused by seismic stress (quake), (kN); $K$ - coefficient depending on seismic zone, ductility, period of oscillation, type of structure; $G$ - weight of the structure - floor slabs, walls, useful load... (kN).

In addition, thick and heavy concrete floor slabs have a high heat capacity due to their high mass per volume and relatively high specific heat capacity of ordinary concrete $(c=960 \mathrm{~J} / \mathrm{kg} \mathrm{K})$.

Specific heat, in this case of concrete, tells us how much energy is needed, measured in joules $(\mathrm{J})$ for a $1 \mathrm{~kg}$ 
mass of concrete to increase its temperature by one Kelvin (1 K).

A lower weight of the floor slabs implies a lower accumulation of heat energy within the slab, as heat capacity of a material depends on the type of the material, as well as on its mass and specific heat capacity, $c$ :

$c=\frac{J}{m^{3} K}$

Where: $c$ - specific heat; $J$ - energy in joules; $m^{3}-$ the volume of the material receiving energy; $K$ - temperature in Kelvin.

According to Eq. (3) thick concrete slabs have high mass and high heat capacity, and they potentially accumulate high amounts of heat and transmit this heat to cooler places, such as walls, foundations, gables, balconies. These "cool places" are hard to insulate and we encounter major losses of energy there (Fig. 6).

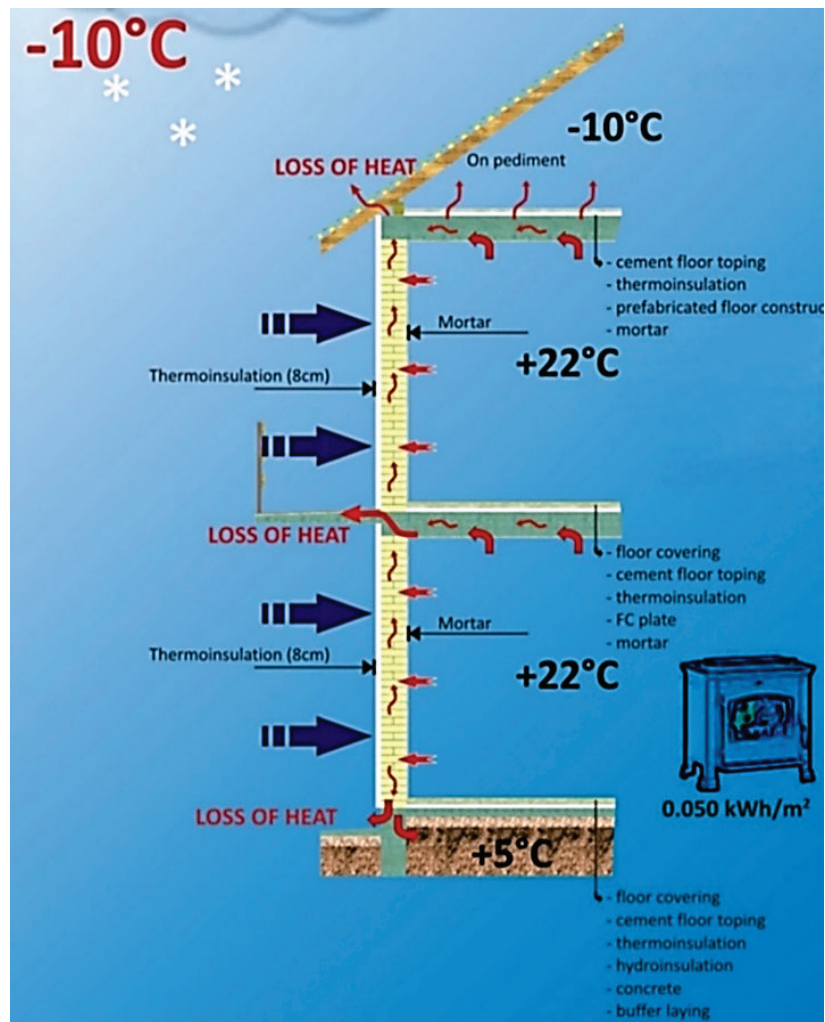

Figure 6 Heat is accumulated at the ceiling; users are on the floor, while heat energy is lost as thick concrete slab transmits heat to "cool places": walls, foundations, balconies, gables...

According to the listed elements, it may be easily concluded that the three aforementioned parameters: adaptability, energy efficiency and seismic safety directly depend on the mass of floor slab:

- Thick solid floor slabs with a solid concrete crosssection of the prescribed and required thickness have a large mass relative to their span, which represents a serious defect and a negative characteristic when it comes to their capability of covering longer spans.

- Thick floor slabs have large mass which produces intense seismic forces $S(\mathrm{kN})$ according to Eq. (2), diminishing the seismic safety of the building in case of seismic activity,
- Thick floor slabs have high heat capacity, according to Eq. (3), with major heat loss through conduction towards cool places (Fig. 7)



Figure 7 Illustration of the negative aspects of thick and heavy concrete floor slabs which hinder adaptability, energy efficiency and seismic safety of residential buildings

When floor slabs are made lighter, then their mass is lower and the following conclusions may be made:

- Concrete floor slabs of reduced weight can span larger distances, as they have low mass for their designed thickness $(d)$ according to the Eq. (1),

- Concrete floor slabs of reduced weight have smaller mass and consequently generate lower seismic forces $S$ (kN) according to Eq. (2). In other words, the lower the mass of the floor slab the weaker is the effect on the seismic force, which in turn implies better safety of the building in this case.

- Concrete floor slabs of reduced weight have low heat capacity as they contain smaller volume of concrete, according to the Eq. (3), with less heat loss through conduction towards cool places (Fig. 8).

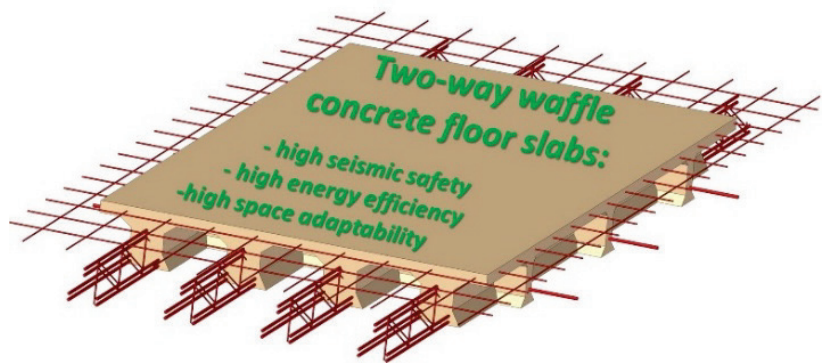

Figure 8 Illustration of the positive correlation between lightweight concrete floor slabs and adaptability, energy efficiency and seismic safety of buildings

This paper could help legislators who stipulate the values of energy efficiency of buildings, to realise that thick and heavy concrete slabs negatively influence energy efficiency of buildings. Legislation on construction could relatively easy condition designers and investors to implement the floor slabs with the mass per square metre at least $45 \%$ lower than the mass of solid concrete slabs of the identical thickness $(d)$ in line with the Eq. (1). Eq. (4) defines the mass of concrete floor slab of reduced weight in relation to the mass of solid RC floor slab:

$M=d \cdot \gamma_{r, c} \cdot 10 \cdot k_{1}\left(\mathrm{kN} / \mathrm{m}^{2}\right)$

Where:

$k_{1} \leq 0,55$ 
$M-$ mass of concrete floor slab with reduced weight $\mathrm{kN} / \mathrm{m}^{2} ; d$ - thickness of the floor slab (m), conditioned by the Eq. (1); $\gamma_{r, c}-$ mass per volume reinforced concrete 2,5 $\mathrm{t} / \mathrm{m}^{3} ; k_{1}$ - coefficient which conditions that the mass per volume of the concrete slab of reduced weight may amount to $55 \%$ of the mass of the imperforated RC floor slab of the same thickness $(d)$.

The data in Tab. 1 clearly show and prove through exact numerical values that traditional heavy solid RC floor slabs should be replaced with two-way waffle RC floor slabs. This could be achieved quite easily and efficiently in case legislators would stipulate that the proposed Eq. (4) and Eq. (5) must be used in designing floor slabs. Waffle $\mathrm{RC}$ floor slabs can be built in various ways. Slab can be made with "permanent shuttering" made of specially shaped expanded polystyrene in line with Stirofert technology [11]. "Permanent shuttering" made of polystyrene implies the structure integrated during the concreting phase in order to form a load-bearing structure of concrete ribs and thin concrete slab. In the phase of utilisation, such slab with "permanent shuttering" demonstrates powerful thermal insulation properties, due to incorporated polystyrene, and at a highly important place, i.e. the ceiling.

Table 1 Practical example demonstrating the characteristics of adaptability, seismic resistance and energy efficiency of two-way waffle RC floor slabs in regard to heavy solid RC floor slabs

\begin{tabular}{|c|c|c|c|c|c|c|}
\hline \multirow{2}{*}{\begin{tabular}{|l|} 
Characteristics \\
Slab span $L(\mathrm{~m})$ \\
\end{tabular}} & \multicolumn{3}{|c|}{$\begin{array}{c}\text { Traditional heavy solid RC } \\
\text { floor slabs }\end{array}$} & \multicolumn{3}{|c|}{ Two-way waffle floor slabs } \\
\hline & 8 & 10 & 12 & 8 & 10 & 12 \\
\hline $\begin{array}{l}\text { Slab thickness }(\mathrm{m}) \\
d \geq \frac{L}{30}\end{array}$ & 0,28 & 0,35 & 0,42 & 0,28 & 0,35 & 0,42 \\
\hline $\begin{array}{l}\text { Mass of the waffle concrete floor slab }\left(\mathrm{kN} / \mathrm{m}^{2}\right) \text { according to the new Eq. (5) and } \\
(6) \text { : } \\
M=d \cdot \gamma_{r, c} \cdot 10 \cdot k_{1}, k_{1} \leq 0,55\end{array}$ & - & - & - & $\begin{array}{c}3,85 \\
\left(k_{1}=0,55\right)\end{array}$ & $\begin{array}{c}4,35 \\
\left(k_{1}=0,5\right)\end{array}$ & $\begin{array}{c}5,04 \\
\left(k_{1}=0,48\right)\end{array}$ \\
\hline $\begin{array}{l}\text { Mass of the traditional heavy solid RC floor slab }\left(\mathrm{kN} / \mathrm{m}^{2}\right) \\
M=d \cdot \gamma_{r, c} \cdot 10\end{array}$ & 7 & 8,75 & 10,5 & - & - & - \\
\hline $\begin{array}{l}\text { Seismic force for the slab with the surface area of } 395 \mathrm{~m}^{2} \\
S=K \cdot M(\mathrm{kN}), K=0,08\end{array}$ & 221,2 & 276,5 & 331,8 & 121,66 & 137,46 & 159,26 \\
\hline $\begin{array}{l}\text { Heat accumulation for the slab with the surface area of } 395 \mathrm{~m}^{2} \text { (specific heat) } \\
c=\frac{J}{m^{3} K} \cdot 2,77 \times 10^{-7}, c=\frac{\mathrm{kW}}{\mathrm{m}^{3} \mathrm{~K}} \\
\left(\mathrm{kWh} / \text { floor slab } 395 \mathrm{~m}^{2}\right)\end{array}$ & 73,73 & 92,16 & 110,6 & 40,55 & 45,82 & 53,09 \\
\hline
\end{tabular}

a)

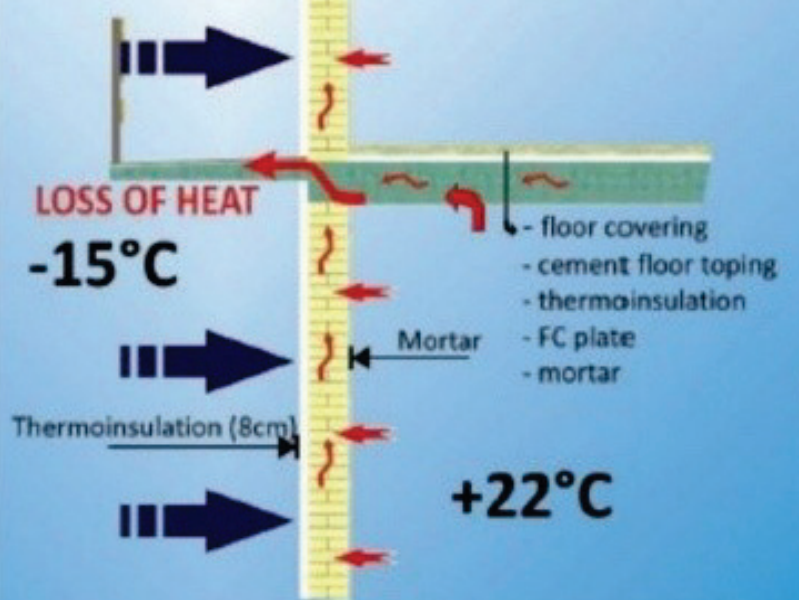

b)



Figure 9 Waffle concrete slab with integrated thermal insulation elements at the ceiling, which prevents accumulation and loss of heat, i.e. its migration from the ceiling to the walls and "cool places"

Application of polystyrene based "permanent shuttering" technique prevents heat energy from penetrating the concrete of the floor slab. Warm air has physical tendency to look for a cooler place and it starts circulating the room eventually reaching the floor. Thereby the temperature of the ceiling and the floor is made equal in an entirely natural way. Users are located near the floor, while their feet, with their inherently weaker circulation, are located on the floor itself. For the users to feel comfortable, their feet need to be warm enough for the blood to flow in an optimal way (Fig. 9)
If designers and investors accepted the design and construction recommendations offered by this scientific work, then the construction of residential buildings would be fast, adaptable, energy efficient, safe in the case of seismic activity, competitive on the market and financially viable with good profit [9]. Fig. 10 shows residential space with prefabricated mountable partitions designed as movable closets, or pieces of furniture, allowing for residential space to be organised in line with the users' needs. In this way, highly pleasant and intimate spaces can be made, sometimes even without doors, or complete 
separation from the rest of the space as in the case of "Casa MJE" (Fig. 10). Such a concept, along with the conditions of ensuring adaptability, represents the highest architectural value of residential and office spaces.

As a confirmation of the two way waffle floor slab, authors present a solution in the form of StiroFert [12] which is patented in several countries in the world (EU, USA, Russian Federation, UAE, etc). The solution had been attested in Spain and Serbia (at the Eduardo Torroja Institude in Madrid, Spain - for carrying capacity (under no. 19.497); at the Afiti Licof Institude in Toledo, Spain for fire resistance (under no. 1890T09); at the Labein Institute in Vitoria, Spain - for acoustics (under no. 90.9736.0-IN-CT-09/30); at the IMS Institute in Belgrade, Serbia - for carrying capacity (under no. IKG 989/08)). StiroFert has been applied on site in several countries in the Southeastern Europe and it has been done mostly in the cases where ranges of application were above $8 \mathrm{~m}$ (Fig. 11 and Fig. 13).
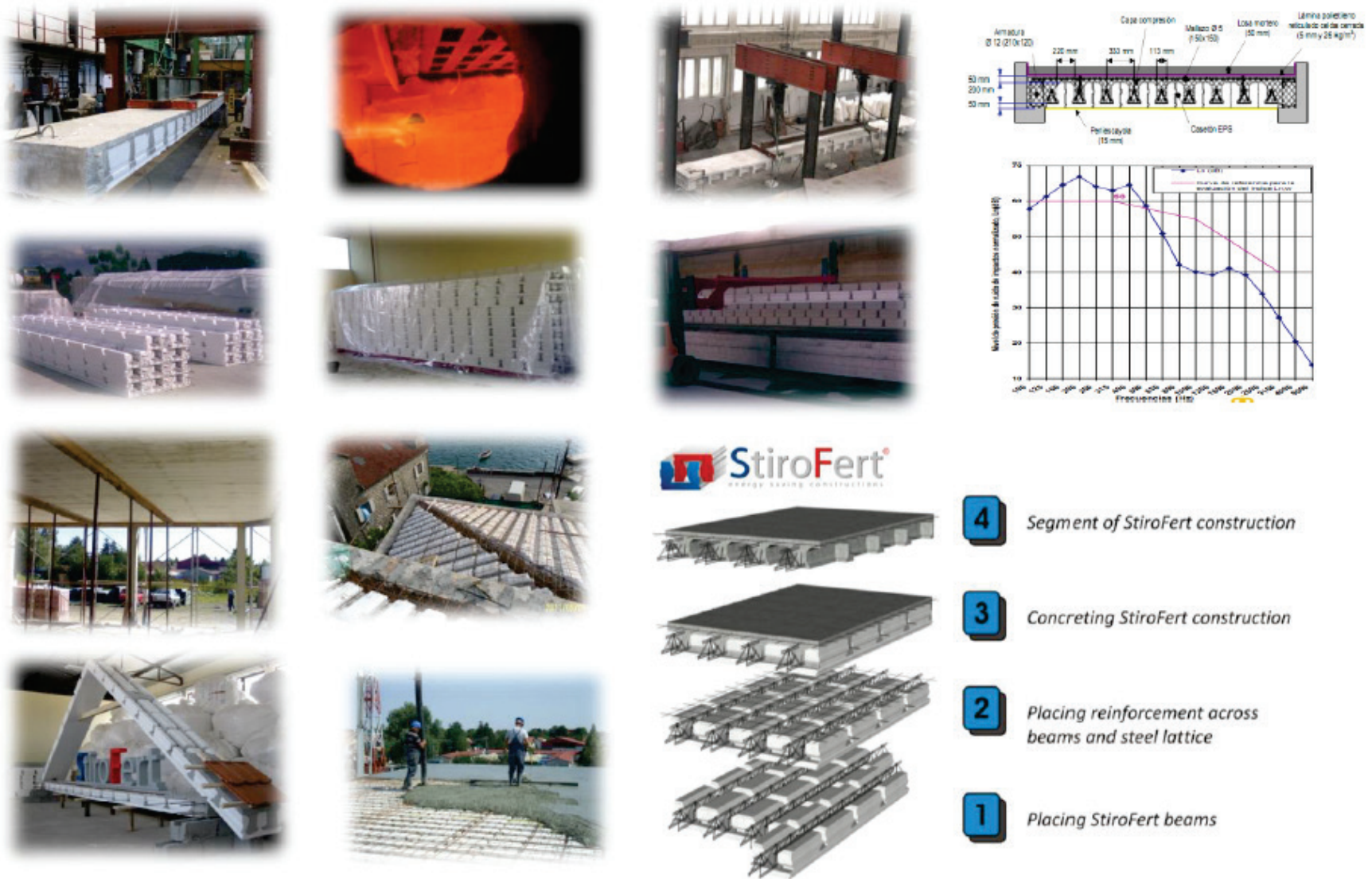

Figure 11 StiroFert in attest stages in Spain and Serbia, and production and application of this solution on objects in the Southeastern Europe [12]

Fig. 12 shows a comparing analysis of the classical full concrete mezzanine plate and the lightened patented StiroFert concrete plate. It shows that the amount of steel reinforcement needed for the realization of the StiroFert solution is $30 \%$ less than the amount needed for the classical thick and full concrete plate. Also, the amount of concrete needed for StiroFert is $56 \%$ less than the amount needed for the classicall full and thick concrete plate.

StiroFert plate has mostly been applied for bigger ranges and carrying capacities of the plate. Fig. 13 shows an example of an application (the contractor contact: www.toncev.com) of a bigger plate applied on the Business building at Hydro power plant "HE Đerdap 2" in Badnjevo on the Danube, with a range of $11,15 \mathrm{~m}$ (a light opening from wall to wall). The thickness of the mezzanine plates is $d=30+5=35 \mathrm{~cm}$. In other applications, the most common are plates which range between 8 and $10 \mathrm{~m}$. 


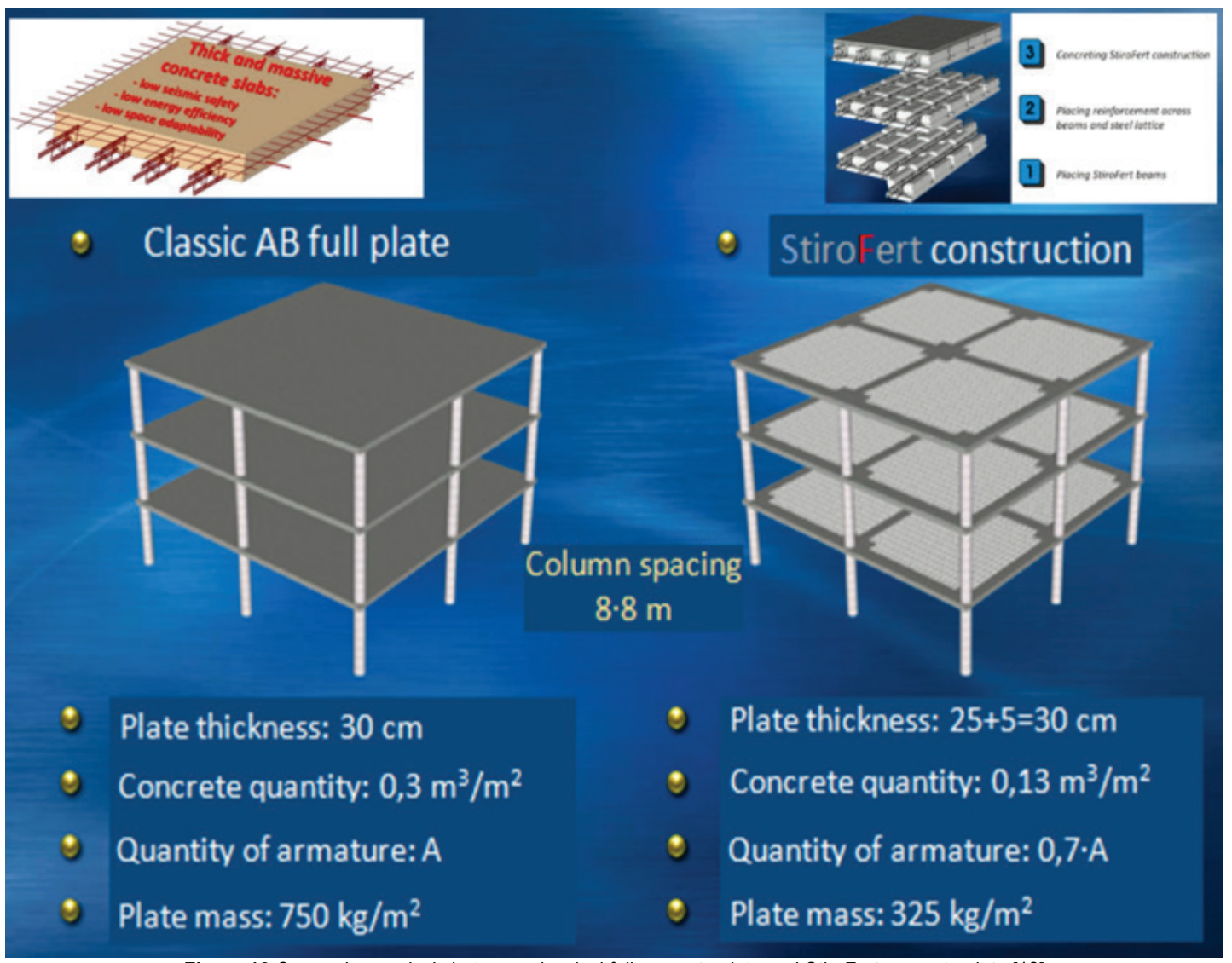

Figure 12 Comparing analysis between classical full concrete plate and StiroFert concrete plate [12]

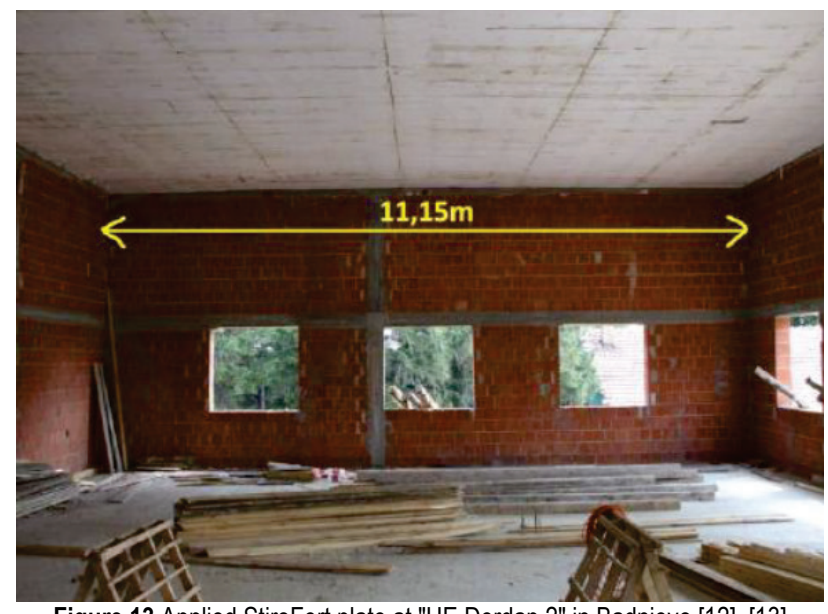

Figure 13 Applied StiroFert plate at "HE Đerdap 2" in Badnjevo [12], [13]

\section{CONCLUSION}

The paper refers to the facts and provides clear arguments that design and construction of buildings must be considered from every aspect, especially from the aspects of flexibility-adaptability, safety and energy efficiency. The design and construction of floor slabs today is done with concrete for several reasons, the most important of which is the fire resistance of such slabs and therefore the buildings themselves. In opposition to steel and wood, concrete is fire resistant, but it also has a big disadvantage, which is the large mass of concrete. The problem is that the large weight of concrete slabs negatively affects the aforementioned required aspects. In order for the floor concrete slabs to have sufficient rigidity and bearing capacity to span certain lengths without the appearance of larger deflections, the thickness of the slabs must satisfy the prescribed conditions given in Eq. (1). A solution in order to reduce the weight of the concrete slabs is for the floor slabs to be designed and constructed as lightened, which would be in the interest of achieving the aforementioned aspects. Today, there is already a legal obligation for the construction of energy-efficient buildings. In the same way, legislators could prescribe that only lighter concrete floor slabs that meet the reduced weight conditions set by the Eq. (4) and Eq. (5) can be designed and constructed. The authors of this paper also suggest that lightened two-way waffle concrete slabs that can be thermally insulated from the bottom be designed and used on ceilings in order to further raise the energy efficiency class.

These equations prescribe that lightened waffle concrete floor slabs have a lower mass, by more than $45 \%$ than conventional thick, solid concrete slabs. Such slabs will be able to span lengths larger than $7 \mathrm{~m}$ in order to achieve higher flexibility and adaptability of the residential space. In the case of seismic activity (earthquakes), buildings with lighter waffle concrete floor slabs will be safer because they lower weight and thus lower horizontal force due to seismic activity, as shown by Eq. (2). In Table 1 , it is clearly demonstrated with exact numerical values that conventional thick and heavy concrete slabs should be replaced by lighter two-way waffle concrete floor slabs. All of the aformentioned arguments lead to a conclusion that the lightened concrete plates should be applied wherever mezzanine plates are needed. There is another argument which was not used in this paper. This argument is aimed at banning the exploatation of river and crushed aggregates in many regions and countries in Europe and the world. As such, we cite the data which states that in some 
regions of Germany there is an increase of prices for concrete aggregates in the amount of $37 \%$. As a consequence, this leads project managers and concrete producers to think of ways to be competitive on the market. The only possible and logical way is to produce lightened concrete plates with optimal - minimal amount of ordinary concrete (Fig. 2, Fig. 5, Fig. 8, Fig. 11, Fig. 12, Fig. 13)

\section{Acknowledgements}

The work reported in this paper is a part of the investigation within the research project III 42012 "Energy efficiency enhancement of buildings in Serbia and improvement of national regulative capacity for their certification", supported by the Ministry for Science and Technology, Republic of Serbia. This support is gratefully acknowledged.

\section{REFERENCES}

[1] Alfirević, Đ. \& Simonović, A. S. (2016).Open-plan in Housing Architecture: Origin, Development and Design Approaches for Spatial Integration. Arhitektura i urbanizam, (43), 45.60. https://doi.org/10.5937/a-u0-11551

[2] Aladžić, V. (2017). The Condition of Immovable Cultural Heritage outside the Urban Context in Vojvodina: the Case Study of the Spitzer Villa in Beočin. Periodica Polytechnica Architecture, 48(1), 45-52. https://doi.org/10.3311/PPar.10410

[3] Gábor-Szabó, Z. (2010). 100-year-old water towers of the Zielinski engineers ' bureau". Periodica Polytechnica Civil Engoneering, 54(2), 171-180. https://doi.org/10.3311/pp.ci.2010-2.13

[4] Schneider, T. \& Till, J. (2005). Flexible housing: Opportunities and limits. Architectural Research Quarterly, 9(2), 157-166. https://doi.org/10.1017/S1359135505000199

[5] Abbaszadeh, S., Kalani Moghadam, M., \& Saadatian, O. (2013). Alyzing a Proper Flexible and Adaptable Pattern for Promoting the Housing Quality in Iran. Journal of Design+Built, 6. Retrieved from http://spaj.ukm.my/jsb/ index.php/jdb/article/view/91

[6] Raviz, S. R. H., Eteghad, A. N., Guardiola, E. U., \& Aira, A. A. (2015). Flexible housing: The role of spatial organization in achieving functional efficiency. Archnet-IJAR, 9(2), 6576. https://doi.org/10.26687/archnet-jjar.v9i2.422

[7] Svirčić Gotovac, A. (2015). The Quality of Living in New Housing Estates in the Settlement Network of Zagreb. In:Kvaliteta života u novostambenim naseljima i lokacijama u zagrebačkoj mreži naselja, 13-44. Zagreb, Republika Hrvatska: Institut za društvena istraživanja.

[8] Jovanovic, G. (2007). Flexible organization of floor composition and flexible organization of dwelling space as a response to contemporary market demands. Facta universitatis - series: Architecture and Civil Engineering, 5(1), 33-47. https://doi.org/10.2298/FUACE0701033J

[9] Jovanović, G., Joković, S., \& Stanimirović, M. (2008). Fleksibilna organizacija sklopa sprata stambenih zgrada kao odgovor na savremen zahteve tržišta. Zbornik radova građevinsko - arhitektonskog fakulteta, (23), 271-278.

[10] Kekanović, M., Šumarac, D., Gligović, D., Ćorić, S., \& Kljajić, Z. (2014). Problems of the Design and Construction of Slab Between Floors. Techical Gazette, 21(3), 631-638. Retrieved from https://hrcak.srce.hr/file/182196

[11] Kekanović, M. (2008). Patent - The possibility of special lightening, insulating and reinforcing intermediate floor constructions; EP 2102426; DE 602006024 757.5; EA 015.878; MX /a/2008/006305; US 12/093,595; UAE 483/2008; PI 0619350-1; MNE 00.560
[12] www.stirofert.com

[13] www.toncev.com

\section{Contact information}

Viktorija ALADžlć, PhD, Assistant Professor Faculty of Civil Engineering Subotica, University of Novi Sad

Kozaračka 2a, 24000 Subotica, Serbia aviktorija@hotmail.com

Milan KEKANOVIĆ, PhD, Associate Professor (Corresponding author)

Faculty of Civil Engineering Subotica,

University of Novi Sad,

Kozaračka 2a, 24000 Subotica, Serbia

kekec@gf.uns.ac.rs

Ilija MILIČIĆ, PhD, Associate Professor Faculty of Civil Engineering Subotica, University of Novi Sad,

Kozaračka 2a, 24000 Subotica, Serbia

ilija.m.milicic@gmail.com 